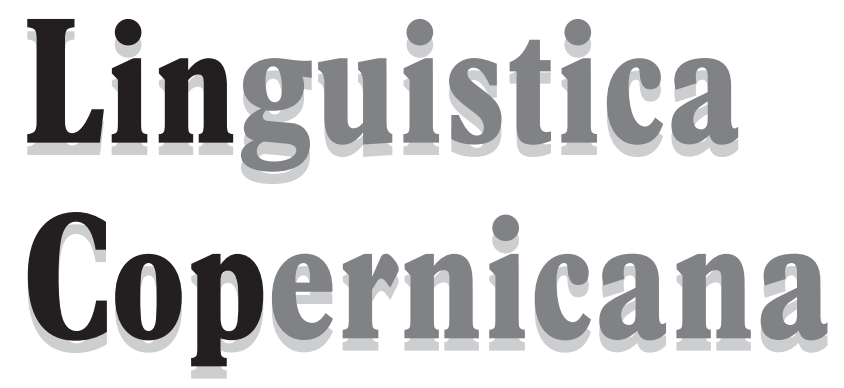

$1(7) / 2012$

WYDAWNICTWO NAUKOWE
UNIWERSytetu MIKOLAJa KOPERNIKA 
REDAKTOR NACZELnY: Maciej Grochowski

Rada Redakcyjna: Ireneusz Bobrowski (Kraków), Andrzej Bogusławski (Warszawa), Gerd Hentschel (Niemcy, Oldenburg), Axel Holvoet (Litwa, Wilno), Krystyna Kleszczowa (Katowice), Roman Laskowski (Kraków), Jarmila Panevová (Czechy, Praha), Jens Nørgård-Sørensen (Dania, Kopenhaga), Zuzanna Topolińska (Macedonia, Skopje), Daniel Weiss (Szwajcaria, Zurich), Anna Wierzbicka (Australia, Canberra)

Kole gi u m R e D K C Y J e: Maciej Grochowski, Krystyna Kallas, Irena Sawicka, Piotr Stalmaszczyk

S E K R ETA R Z R E D A K C I: Iwona Kaproń-Charzyńska

A D R E S R E D A K C J I: Instytut Języka Polskiego UMK, 87-100 Toruń, ul. Fosa Staromiejska 3, e-mail: lincop@umk.pl,www.linguistica.umk.pl

OKŁ A D K A: Monika Pest

(C) Copyright by Wydawnictwo Naukowe Uniwersytetu Mikołaja Kopernika

Toruń 2012

ISSN 2080-1068

Wersją pierwotną (referencyjną) czasopisma jest wersja papierowa.

WYDAWNICTWO NAUKOWE UNIWERSYTETU MIKOEAJA KOPERNIKA

Redakcja: ul. Gagarina 5, 87-100 Toruń

tel. (56) 6114295 , tel./fax 6114705

e-mail: wydawnictwo@umk.pl

Dystrybucja: ul. Reja 25, 87-100 Toruń

tel./fax (56) 61142 38, e-mail: books@umk.pl

www.wydawnictwoumk.pl

Druk: Wydawnictwo Naukowe UMK 


\section{Wykładniki struktury tematyczno-rematycznej w języku lacińskim}

Słow a klucze: struktura tematyczno-rematyczna, język łaciński, szyk w języku łacińskim, uwydatniony temat, uwydatniony remat.

Nie ulega wątpliwości, że w łacinie, języku fleksyjnym, a co za tym idzie, niepozycyjnym, podstawowym wykładnikiem struktury tematyczno-rematycznej jest szyk. Ponieważ od pewnego czasu dostrzega się, a dotyczy to badaczy różnych orientacji metodologicznych, że pojęcie struktury tematyczno-rematycznej stanowi podstawowe narzędzie rozumienia szyku w języku łacińskim, pojawiło się szereg opracowań poświęconych temu zagadnieniu. Pierwsza tego typu pracę stanowi The communicative perspective in the sentence: a study of Latin word order Dirka Panhuisa (1982), w której autor do opisu szyku łacińskiego posłużył się teorią funkcjonalnej perspektywy zdania Jana Firbasa (por. Firbas 1992). Z nowszych opracowań warto wymienić Latin Word Order. Structured Meaning and Information Andrew Devine'a i Laurence Stephensa (Devine, Stephens 2006), w której zastosowano metodologię generatywną. W najnowszej, o ile wiem, pracy na ten temat, Constituent Order in Classical Latin Prose, autorka, Olga Spevak (2010), posługuje się w opisie zagadnień szyku łacińskiego własną, zmodyfikowaną wersją

1 Wcześniejsze prace tego typu, częściowo dotyczące łaciny, to Polo (2004), a także Salvi (2004). 
gramatyki funkcjonalnej Simona Dika (por. Dik 1978). Jako że wszystkie te prace poruszają szereg niekiedy bardzo szczegółowych zagadnień, przy czym każdy z autorów wprowadza inny aparat pojęciowy i terminologiczny, nawet sktótowe zaprezentowanie założeń i wniosków płynących z tych opracowań przekracza ramy tego artykułu². W związku z tym ograniczę się do przedstawienia najważniejszych ustaleń, dotyczących relacji między szykiem a strukturą tematyczno-rematyczną w łacinie, a następnie skupię się na innych niż szyk wykładnikach tematu i rematu.

Łacina jest językiem o tzw. swobodnym szyku, czy, jak wolą niektórzy, elastycznym (zob. np. Magni 2009: 227), jako że nie jest on całkowicie swobodny, zatem punktem wyjścia do pokazania roli szyku jako wykładnika struktury tematyczno-rematycznej jest ustalenie szyku neutralnego, nienacechowanego. W tradycyjnych opracowaniach uznaje się, że czasownik łaciński, stanowiący najważniejszy element zdania, z zasady zajmuje pozycję końcową, a inne jego umiejscowienie ma charakter odstępstwa od tej normy. I tak, biorąc pod uwagę pozycję verbum finitum, końcową lub nie-końcową, Hofmann, Szantyr (1965: 397-398) oraz Kühner, Stegmann (1962: 589-590) dokonują rozróżnienia na szyk tradycyjny i okazjonalny, a Marouzeau (1938) na nienacechowany i nacechowany. Jak zauważają Spevak (2009: 2) i Magni (2009: 227), traktowanie końcowej pozycji czasownika jako normy wynika nie tylko z analiz tekstów, zwłaszcza autorów klasycznych, Cycerona i Cezara, ale także z zaleceń Kwintyliana:

Verbo sensum cludere multo, si compositio patiatur, optimum est: in verbis enim sermonis vis est. /Quint. Inst. 9, 4, 26/

Czasownikiem zamknąć sens, jeśli na to pozwala kompozycja, jest zdecydowanie najlepiej: w czasownikach bowiem tkwi siła wypowiedzi.

Jednocześnie stwierdzano, że inicjalna pozycja w zdaniu w sposób niejako naturalny jest zarezerwowana dla podmiotu, zaś dopełnienie i pozostałe określenia są usytuowane w środku zdania (zob. np. Kühner, Stegmann 1962: 590, 597). Kiedy więc Greenberg (1963: 76-78) przedstawił swoją typologię, opartą o podstawowy dla danego języka szyk, stwierdzając, jak wiadomo, że najczęściej spotykane są trzy typy szyków: SOV, SVO i VSO (jako że

2 Pracę Panhiusa krótko omawia Spevak (2010: 4-6). 
trzy pozostałe możliwe typy szyków, czyli VOS, OSV i OVS, występują bardzo rzadko), niemal automatycznie uznano, że łacina reprezentuje typ języka o szyku SOV. Jednakże wyniki szczegółowych analiz zachowanych tekstów, zwłaszcza w zestawieniu z niektórymi zaproponowanymi przez Greenberga uniwersaliami językowymi, wzbudziły wątpliwości, co do tego, czy w łacinie rzeczywiście nienacechowany jest tylko jeden typ szyku i czy jest to szyk SOV. Wprawdzie reguła 41 potwierdza zależność między tym typem szyku a występowaniem w języku fleksji imiennej ${ }^{3}$, jednak inne uniwersalia już nie są prawdziwe w odniesieniu do języka łacińskiego. Chodzi przede wszystkim o regułę 4, zgodnie z którą w językach o szyku SOV przyimki występują w postpozycji. ${ }^{4} \mathrm{~W}$ łacinie, poza kilkoma wyjątkami ${ }^{5}$, wszystkie przyimki znajdują się w prepozycji. Poza tym, zgodnie z regułami 2 i 5, przydawki przymiotne i dopełniaczowe powinny poprzedzać rzeczowniki, do których się odnoszą, gdy tymczasem w łacinie zwykle po nich następują ${ }^{6}$. Zatem zgodnie z kryteriami zaproponowanymi przez Greenberga, należałoby przyjać, że w łacinie występują dwa typy szyku: SOV i SVO. W związku $\mathrm{z}$ tym, uwzględniając tak istotną $\mathrm{w}$ języku łacińskim perspektywę diachroniczną, część badaczy uznała, że w łacinie archaicznej i klasycznej podstawowy był szyk SOV, który z czasem stopniowo przechodził w szyk SVO,

3 Zob. Greenberg (1963: 95): „Universal 41: If in a language the verb follows both the nominal subject and nominal object as the dominant order, the language almost always has a case system."

${ }^{4}$ Zob. Greenberg (1963: 79): „Universal 4: With overwhelmingly greater than chance frequency, languages with normal SOV order are postpositional."

5 Są to ,poimki” causa (np. doktorat honoris causa - doktorat dla zaszczytu), gratia (np. exempli gratia - dla przykładu) i ergo (np. virtutis ergo - ze względu na męstwo), które ponadto łączą się z genetiwem, w odróżnieniu od pozostałych przyimków, łączących się z accusatiwem lub ablatiwem. Oprócz tego w postpozycji (jako enklityka) pojawia się przyimek cum w połączeniu z ablatiwem zaimków osobowych (np. mecum - ze mną, vobiscum - z wami), a niekiedy także versus z rzeczownikami w accusatiwie (np. domum versus - $\mathrm{ku}$ domowi) oraz tenus $\mathrm{z}$ rzeczownikami w ablatiwie (np. genu tenus aż do kolana) lub w genetiwie (np. talorum tenus - aż do kostek).

${ }^{6}$ Zob. Greenberg (1963: 78): „Universal 2: In languages with prepositions, the genitive almost always follows the governing noun, while in languages with postpositions it almost always precedes.” i Greenberg (1963: 79): „Universal 5: If a language has dominant SOV order and the genitive follows the governing noun, then the adjective likewise follows the noun." 
występujący w językach romańskich, zwłaszcza w języku francuskim ${ }^{7}$ Inni natomiast, m.in. Adams (1976) i Panhuis (1984), są zdania, że szyk SVO pojawił się już w łacinie archaicznej i że te dwa typy szyku współwystępowały ze sobą przez całą historię łaciny, także w łacinie okresu klasycznego, przy czym szyk SOV właściwy był jedynie tekstom prozy klasycznej (z Cezarem na czele) i stanowił specyficzne stylistyczne nacechowanie tych tekstów, nie mające nic wspólnego z językiem mówionym, gdzie naturalny był szyk SVO. Ponieważ jednak badania Harma Pinkstera (1990: 163-189), dotyczące szyku w tekstach reprezentujących najbardziej kolokwialną łacinę okresu klasycznego do jakiej mamy dostęp, to znaczy w listach Cycerona, zwłaszcza do Attyka, tego nie potwierdzają, można przyjąć, że przynajmniej w tekstach klasycznych szyk SOV jest szykiem neutralnym ${ }^{8}$.

Oczywiste jest, że zdania empiryczne, będące częścią większych jednostek tekstowych, zwykle składają się z większej liczby elementów niż tylko podmiot, dopełnienie i orzeczenie, i że liczba tych elementów i ich wzajemne uporządkowanie zależy od wielu różnych czynników, przy czym nakładają się na nie jeszcze różnice w budowie zdań pojedynczych i zdań złożonych, zwłaszcza podrzędnie. Zatem ukazanie zależności między szykiem a budową tematyczno-rematyczną jest niezwykle skomplikowane, czego dowodzą przywołane na początku prace, poświęcone tym zagadnieniom. Dlatego też ograniczę się do omówienia kilku kwestii związanych z budową tematyczno-rematyczną a dwiema nacechowanymi pozycjami w zdaniu łacińskim, tj. pozycją początkową i końcową.

Uznając za neutralny szyk SOV, można przyjąć, że pozycje te zarezerwowane są odpowiednio dla podmiotu, będącego tematem, i verbum finitum, które, wraz z określeniami, stanowi remat zdania, jak w przykładzie (1)9

(1) Helvetii... legatos ad eum mittunt. /Caes. Gall. 1, 13, 2/

Helweci posłów do niego wysyłają.

7 Szyk łaciński w ujęciu diachronicznym, od stanu praindoeuropejskiego po sytuację w językach romańskich, opisuje Bauer (1995) i (2009). Zob. także Magni (2009).

${ }^{8}$ Zob. też. Pinkster (1991).

9 Przy przytaczaniu fragmentów utworów źródłowych stosuję system skrótów przyjęty w Plezia (1998: XLIII-XLIV); lista źródeł znajduje się na końcu artykułu. Rezygnuję z zamieszczania przekładów literackich tych fragmentów na rzecz własnych tłumaczeń, w których pozostawiam szyk zbliżony, na ile to możliwe, do oryginalnego. 
Umieszczenie na pozycji końcowej jakiegoś innego niż verbum finitum elementu powoduje, że ten właśnie element, a nie verbum finitum, staje się rematem zdania (por. Pinkster 1990: 178-179). I tak, w przykładach (2), (3) i (4) końcową pozycję zajmują składniki wprowadzające nową dla odbiorcy informację, w (2) o tym, kogo nie można znaleźć, w (3) od kogo można uzyskać informacje, a w (4) czas zgonu ojca, ponieważ sam fakt był odbiorcy znany:

(2) ...non invenio fidelem tabellarium. /Cic. Att. 1, 13, 1/

Nie mogę znaleźć wiarygodnego posłańca.

(3) verum haec audies de Philadelpho. /Cic. Att. 1, 11, 2/

Ale tego dowiesz się od Filadelfa.

(4) pater nobis decessit a.d. VIII Kal. Dec. /Cic. Att. 1, 6, 2/

Ojciec mi umarł 23 listopada.

W przytoczonych przykładach po verbum finitum pojawiły się dopełnienia i okolicznik czasu, ale na pozycję końcową może być przesunięty również podmiot, kiedy jest rematem zdania ${ }^{10}$, jak w przykładzie (5):

(5) Patrem occidit Sex. Roscius. /Cic. S. Rosc. 39/

Ojca zabił Sekstus Roscjusz.

Jeśli zaś chodzi o pozycję inicjalną, przyjmuje się, że zasadniczo zajmuje ją element pełniący funkcję tematu. Zagadnienie to jest jednak znacznie bardziej skomplikowane (por. Pinkster 1990: 169-178). Jako przykład dla zilustrowania choćby części problemów z tym związanych mogą posłużyć zdania z punktu (6), którymi Cyceron kończy list do swojego przyjaciela Attyka:

10 Więcej na temat szyku VS - zob. Bolkestein (1995). 
(6) a. Quintum fratrem cottidie exspectamus. b. Terentia magnos articulorum dolores habet. c. et te et sororem tuam et matrem maxime diligit salutemque tibi plurimam adscribit et Tulliola.../Cic. Att. 1, 5, 8/

a. Brata Kwintusa codziennie oczekujemy. b. Terencja silne stawów bóle odczuwa. c. I ciebie, i twoją siostrę, i matkę bardzo kocha, pozdrowienia dla ciebie serdeczne dołącza także Tuliola...

Jak widzimy, tylko w zdaniu drugim ( 6 b.) ma miejsce sytuacja ,wzorcowa", to znaczy pozycję inicjalną zajmuje podmiot Terentia, który jest też W zdaniu tematem. ${ }^{11} \mathrm{~W}$ zdaniu pierwszym (6 a.) również występuje szyk SOV, jednak mamy tu do czynienia z tzw. podmiotem domyślnym (zaimkiem pierwszej osoby liczby mnogiej). Funkcję tematu zaś pełni dopełnienie Quintum fratrem, które, podobnie jak podmiot Terentia w następnym zdaniu, wskazuje element wypowiedzi znany odbiorcy, nowa zaś jest informacja o tym, że jest codziennie oczekiwany (tzn. w każdej chwili może się pojawić) ${ }^{12}$. Przykład trzeci (6 c.) zaś pokazuje niezwykle częstą sytuację, kiedy to pierwszą pozycję w zdaniu zajmują elementy spajające tekst: należą do nich przede wszystkim spójniki, jak w tym przypadku et, ale mogą to też być różnego typu zaimki anaforyczne (rzeczowne, np. is - ten, ille - tamten, przymiotne, np. talis - taki, i przysłówkowe, np. tunc - wtedy ${ }^{13}$. Różnica między spójnikami a wyrazami anaforycznymi polega na tym, że te pierwsze de facto nie są elementami zdania i nie mogą w związku z tym pełnić funkcji tematu (mimo że znajdują się na pozycji inicjalnej), tak jak w podanym przykładzie, gdzie w roli tematu występują, pojawiające się po spójniku, szeregowe dopełnienia te, sororem i matrem.

Inicjalną pozycję w zdaniu łacińskim może zajmować także verbum finitum $^{14}$. Zdarza się to często $\mathrm{w}$ zdaniach rozkazujących i pytających. Zda-

11 Różne czynniki warunkujące inicjalną pozycję podmiotu omawia De Jong (1989).

12 Nie tylko w przypadku zaimków pierwszej i drugiej osoby mamy do czynienia z podmiotami domyślnymi. Również pozycja podmiotu trzecioosobowego jest wypełniana tylko wtedy, gdy nie jest on oczywisty na podstawie poprzedzającego kontekstu. Zatem bardzo wiele zdań nie zawiera eksplicytnego podmiotu i w związku z tym inicjalną pozycję zajmują w nich inne elementy.

13 Przeglądu elementów zajmujących inicjalną pozycję w zdaniu łacińskim dokonuje też Spevak (2010: 13-15).

14 Wiele miejsca inicjalnej pozycji czasownika w zdaniu łacińskim poświęcają Devine, Stephens (2006: 145-172), a także Bauer (2009: 275-280). 
nia rozkazujące mogą oczywiście rozpoczynać się od podmiotu, zwłaszcza jeśli jest to zaimek drugiej osoby, a zdanie ma charakter przeciwstawny, jak w przykładzie (7):

(7) Vos vero, patres conscripti, conservate auctoritatem vestram, manete in sententia.../Cic. Phil. 14, 3/

Wy zaś, senatorowie, zachowajcie waszą powagę, pozostańcie przy [swoim] zdaniu...

Zwykle jednak nie zawierają podmiotu, a pozycję inicjalną zajmuje w nich czasownik:

(8) inferte oculos in curiam, introspicite penitus in omnis rei publicae partis.../Cic. Font. 43/

Skierujcie oczy na senat, spójrzcie głębiej we wszystkie części rzeczpospolitej...

Na początku może się również sytuować czasownik w niektórych zdaniach pytajnych, na przykład w pytaniach o rozstrzygnięcie z enklityczną partykułą pytajną -ne (czy):

(9) Dixeritne L. Vettius in contione tua rogatus a te sese auctores et impulsores et socios habuisse sceleris illius eos viros... /Cic. Vat. 24/

Czy powiedział L. Wettjusz na twoim zgromadzeniu poproszony przez ciebie, że jako doradców, podżegaczy i towarzyszy tej zbrodni miał tych mężów...

Znacznie bardziej interesujące są jednak sytuacje, gdy czasownik znajduje się na początku zdań oznajmujących, jak w przykładach (10) i (11):

(10) erant omnino itinera duo, quibus itineribus domo exire possent: unum per Sequanos, angustum et difficile... alterum per provinciam nostram, multo facilius atque expeditius.../Caes. Gall. 1, 6, 1/

Były w ogóle drogi dwie, którymi [to] drogami z domu wyjść mogli: jedna przez [terytorium] Sekwanów, wąska i trudna... druga przez prowincję naszą, znacznie łatwiejsza i wygodniejsza... 
(11) relinquebatur una per Sequanos via, qua Sequanis invitis propter angustias ire non poterant. /Caes. Gall. 1, 9, 1/

Pozostawała jedynie przez [terytorium] Sekwanów droga, którą wbrew woli Sekwanów z powodu ciasnoty przejść nie mogli.

Zdania takie, gdzie w roli verbum finitum bardzo często pojawiają się czasowniki o znaczeniu być, istnieć, mieć miejsce, przebywać itp., określane są w literaturze (Pinkster 1990: 183-184; Spevak 2010: 56-57, Rosén 1998) jako presentative sentences, czyli zdania wprowadzające informacje całkowicie nowe dla odbiorcy, dotyczące takich przedmiotów czy zjawisk, o których odbiorca nie może nic wiedzieć. Ze względu na charakter zachowanych tekstów łacińskich, wśród których znaczną część stanowi choćby historiografia, zdania takie spotyka się dość często. Przyjmuje się (np. Pinkster 1990: 184), że wypowiedzenia tego rodzaju nie są rozczłonkowane tematyczno-rematycznie, to znaczy nie ma w nich wskazanego tematu, są więc czysto rematyczne ${ }^{15}$. W takim kierunku, jak się wydaje, zmierza m.in. Olga Spevak (2010: 56-57), stwierdzając, że wprowadzają one tzw. future topic, tj. element, który stanie się tematem w kolejnych zdaniach. Jako przykład przytacza następujące zdanie:

(12) Erat ea tempestate Romae Numida quidam nomine Massiva, Gulussae filius, Masinissae nepos, qui... profugus ex patria abierat. huic Sp. Albinus, qui proxumo anno... consulatum gerebat, persuadet... /Sal. Jug. 35, 1-2/

Przebywał w tym czasie w Rzymie pewien Numidyjczyk o imieniu Massiva, syn Gulassy, wnuk Masynissy, który... jako zbieg z ojczyzny uciekł. Jego Spuriusz Albinus, który w ostatnim roku... sprawował konsulat, przekonuje...

w którym future topic pojawia się $\mathrm{w}$ następnym zdaniu w postaci zaimka anaforycznego huic.

Jak wspomniałam przy okazji omawiania zdania (6 c.), istnieją takie elementy językowe, które z zasady zajmują w zdaniu pozycję inicjalną, nieza-

15 Podobna sytuacja ma miejsce w przypadku zdań spostrzeżeniowych, na które zwraca uwagę R. Huszcza (1990a). 
leżnie od jego dalszego uporządkowania. Są to przede wszystkim niektóre spójniki, zwłaszcza parataktyczne, ale też hipotaktyczne (por. Pinkster 1990: 169-170). Jako przykład może posłużyć spójnik wynikowy itaque, który właściwie zawsze znajduje się na początku zdania:

(13) Itaque viri fortissimi atque honestissimi qui ordines duxerunt res et iudicant et iudicaverunt. /Cic. Phil. 1, 20/

Zatem mężowie najdzielniejsi i najuczciwsi, którzy stanom przewodzili, sprawę rozsądzają i rozsądzali.

Zmiana inicjalnej pozycji takiego elementu, do której niekiedy dochodzi, powoduje, jak się wydaje, że składnik, który jest przesunięty na początek, nabiera charakteru rematu ,podkreślonego (wskazanego z naciskiem)”, jak to ujmuje A. Weinsberg (1983: 228), czy też „uwydatnionego”, jak to określa R. Huszcza (1983: 100). Taka sytuacja ma miejsce w przykładzie (14), gdzie spójnik ten nietypowo znalazł się na drugiej pozycji, uwydatniając tym samym remat zdania:

(14) pro ingenti itaque victoria id fuit plebi. /Liv. 4, 54, 6/

Za wielkie więc zwycięstwo uznał to lud.

Oprócz tego rodzaju inwersji łacina dysponuje także innym środkiem służącym do uwydatnienia rematu. Jest nim spotykany w wielu językach, m.in. we francuskim czy angielskim, tzw. clefting (por. Weinsberg 1983: 229). W łacinie takie konstrukcje, choć nie tak częste, jak w językach romańskich, są również zauważalne i prawdopodobnie są ich źródłem (zob. Löfstedt 1966, Bauer 2009: 282-286; a także Spevak 2010: 55-56). Zbudowane są tak, że na pozycji inicjalnej występuje rzeczownik, zaimek osobowy lub wskazujący, następnie forma osobowa esse (być), dla której jest on podmiotem i wreszcie odnoszące się do niego zdanie względne, jak w przykładach (15)-(18):

(15) Charilaus fuit qui ad Publilium Philonem venit... /Liv. 8, 25, 10/

[To] Charilaus był tym, który do Publiliusza Filona przyszedł... 
(16) temperantia est enim, quae in rebus aut expetendis aut fugiendis ut rationem sequamur monet. /Cic. Fin. 1, 47, 4/

[To] umiarkowanie jest bowiem tym, co [nas], abyśmy w dążeniu do pewnych rzeczy albo w ich unikaniu rozumem się kierowali, napomina.

(17) ...tu es qui diligentissime pretia exquisisti, qui, ut ais, magno vendidisti.../Cic. Verr. 2, 3, 71, 6/

[To] ty jesteś tym, który bardzo pilnie wartość sprawdzał, który, jak mówisz, drogo sprzedał...

(18) ...haec illa est autem, quam emi de praeda. /Plaut. Epid. 621/

[To] ona jest tą, którą kupiłem za łup.

Oprócz tego clefting dość często występuje w łacinie w zdaniach pytajnych, w postaci wyrażeń quis est qui (czy jest ktoś taki, kto) i quid est quod (czy jest coś takiego, co) (zob. Menge 2000: 554):

(19) Quis est enim qui tueri possit liberum nostrorum pueritiam contra improbitatem magistratuum? /Cic. Verr. 2, 1, 153, 9/

Czy jest ktoś taki, kto strzec mógłby dzieciństwa naszych dzieci przed niegodziwością urzędników?

(20) quid est quod de hoc dici possit? /Cic. Verr. 2, 1, 118/

Czy jest coś takiego, co o tym powiedzieć można?

Nieco bardziej zróżnicowane środki służą w języku łacińskim do podkreślenia, czy też uwydatnienia tematu ${ }^{16}$. Jednym z nich jest konstrukcja korelacyjna, będąca niejako odwrotnością cleftingu (zob. Bauer 2009: 258-259). Na podstawie tekstów z epoki archaicznej, można stwierdzić, że początkowo składała się ona $\mathrm{z}$ dwóch wzajemnie od siebie zależnych zdań, z których pierwsze, wprowadzane przez zaimek nieokreślony quilquod (ktokolwiek/ cokolwiek) nie mogło istnieć bez drugiego, rozpoczynającego się od zaim-

\footnotetext{
16 Uwydatniony temat definiuje Huszcza (1983: 99).
} 
ka anaforycznego is/id (ten/to), i odwrotnie, zdanie drugie nie mogło istnieć bez pierwszego:

(21) quae arida erunt... ea omnia eximito... /Cato Agr. 44/

Jakiekolwiek były suche... te wszystkie przycinaj...

Z czasem tego typu konstrukcje przekształciły się w zdania niewspółrzędnie złożone, gdzie kolejność została odwrócona i drugie stało się względne (ea eximito, quae arida sunt - przycinaj te, które są suche). Część jednak zachowała się albo jako stwierdzenia ogólne o charakterze warunkowym, niekiedy będące przysłowiami:

(22) quod licet Iovi (id) non licet bovi.

Co wolno Jowiszowi, tego nie wolno wołowi.

(23) qui palam est adversarius, eum facile cavendo evites. /Cic. Verr. 2, 1, 39/

Kto jawnie jest wrogi (jeśli ktoś jawnie jest wrogi), tego łatwo wystrzegając się unikniesz.

albo też ten pierwotnie niekreślony element quilquod służył właśnie do uwydatnienia tematu:

(24) quae mihi antea signa misisti, ea nondum vidi; in Formiano sunt... /Cic. Att. 1, 4, 3, 5/

Które mi wcześniej posagi wysłałeś, tych jeszcze nie widziałem; są w Formianum...

Oprócz konstrukcji korelacyjnych łacina dysponuje także innymi wykładnikami uwydatnionego tematu. Są to przede wszystkim takie wyrażenia, które w gramatyce funkcjonalnej określa się jako theme, czyli człon tematyczny znajdujący się poza obrębem predykacji (co do..., to...; jeśli chodzi o..., to), w odróżnieniu od topic, czyli członu tematycznego będącego w obrębie predykacji (Jan śpi) (zob. Huszcza 1990b: 59 przyp. 8; Dik 1978: 127-156; Pinkster 1990: 38; Spevak 2010: 107-111). Najczęściej taką rolę pełni wyra- 
żenie przyimkowe de + ablativus (zob. Somers 1994: 151), jak w przykładach (25), (26) i $(27)^{17}$ :

(25) de Pompeio, et facio diligenter et faciam quod mones. /Cic. Q. fr. 3, 1, 9/ Co do Pompejusza, i wykonuję bardzo starannie, i będę wykonywał to, co zalecisz.

(26) De domo et Curionis oratione, ut scribis ita est. /Cic. Att. 3, 20, 2/

Co do [mojego] domu i mowy Kuriona, jak piszesz, tak jest.

(27) de forma, ovem esse oportet corpore amplo. /Varro Rust. 2, 2, 3/

Co do wyglądu, owca powinna odznaczać się obfitym ciałem.

Martje Somers (1994: 161) zwraca uwagę, że tego rodzaju tematy nie pojawiają się we wszystkich typach tekstów. Są one charakterystyczne dla języka codziennego i dla różnego rodzaju poradników, stąd też można je spotkać w komediach Plauta, listach Cycerona i traktacie rolniczym Warrona.

Za kolejny typ tematu, w sensie theme, czyli elementu poza predykacją, można, jak się wydaje, uznać dostrzeżony przez tradycyjną gramatykę łacińską tzw. nominativus explicativus lub pendens (czyli wyjaśniający albo zawieszony w powietrzu). Jak pisze Safarewicz (1950: 19), „Nieraz się zdarza, że osoba mówiąca wysuwa nazwę przedmiotu lub pojęcia w nom[inatiwie] poza właściwe zdanie, ponieważ chce położyć na ten wyraz szczególny nacisk.” Rozpoczynający zdanie rzeczownik albo zaimek w nominatiwie nie jest więc z tym zdaniem składniowo powiązany, co pokazują następujące przykłady:

(28) tu, si te di amant, agere tuam rem occasiost. /Plaut. Poen. 659/

Ty, jeśli cię bogowie kochają, załatwić twoją sprawę jest sposobność.

17 Wyrażenie takie stanowi temat oczywiście pod warunkiem, że znajduje się w prepozycji wobec predykacji i składniowo w żaden sposób nie jest z nią powiązane. Inaczej jest w sytuacji, gdy de + ablativus jest częścią predykacji, np. w Cic. Att. 15, 1, 2: De Antonio iam antea tibi scripsi non esse eum a me conventum (O Antoniuszu już ci wcześniej napisałem, że go nie spotkałem), gdzie de Antonio jest dopełnieniem do scripsi. 
(29) ceterae philosophorum disciplinae, omnino alia magis alia, sed tamen omnes... nihil adiuvare arbitror.../Cic. Fin. 3, 11, 12/

Pozostałe nauki filozofów, w ogóle jedna bardziej niż inna, lecz żadne... nie są pomocne, jak sądzę...

(30) sed urbana plebes, ea vero praeceps erat. /Sal. Cat. 37, 4/

Lecz lud miejski, on rzeczywiście się pospieszył.

Gramatyki łacińskie, na przykład Kühner, Stegmann (1962: 586-7) czy Menge (2000: 894), traktują tego typu konstrukcje jako rodzaj anakolutu, który daje efekt emfazy, stąd Hofmann, Szantyr (1965: 29-30) określają go jako der isoliert-emphatische Nominativ. Zatem funkcja tego typu nominatiwu, polegająca na uwydatnieniu tematu, zdaje się nie budzić wątpliwości ${ }^{18}$.

Oprócz tego w roli wykładnika uwydatnionego tematu może być użyte w łacinie niezależne od predykacji wyrażenie quod pertinet ad... (co się tyczy...) (zob. Spevak 2010: 111):

(31) quod quidem ad nos duas attinuit, praepotentes pulchre pacisque potentes, soror, fuimus... /Plaut. Poen. 1181-1182/

Co się zaś nas dwóch tyczy, miałyśmy władzę, siostro, i decydowałyśmy o pokoju...

W ramach szeroko pojętego tematu, obok theme i topic, gramatyka funkcjonalna wyróżnia także tail (tren), tj. człon tematyczny, który występuje po zdaniu, np. Nigdy go tu nie byto, tego Jana (zob. Huszcza 1990b: 59 przyp. 8; Dick 1978: 127-156). Człon ten objaśnia, dookreśla składnik, który się pojawił w zdaniu lub też uściśla treść całego zdania (por. Spevak 2010: 111-114). Nie jest to częsty sposób uwydatnienia tematu w języku łacińskim, jednak, jak się wydaje, tak właśnie można zinterpretować przykłady (32) i (33):

18 Zob. Pinkster (1990: 38) czy Rubio (2009: 205). G. Rubio (2009: 206) zwraca ponadto uwagę, że nominativus pendens, występujący zarówno w tekstach archaicznych i klasycznych, jak i późnych, za pomocą którego dokonywała się topikalizacja jakiegoś elementu wypowiedzi, należy odróżniać od podobnego nominatiwu pojawiającego się w łacinie biblijnej jako kalka z języka hebrajskiego, np. Vulg. PS. 10, 5: Dominus in caelo sedes eius, oculi eius in pauperem respiciunt (Pan, w niebie siedziba jego, oczy jego na biedaka patrzą). 
(32) Hercle te hau sinam emoriri, nisi mi argentum redditur, viginti minae. /Plaut. Pseud. 1222-1223/

$\mathrm{Na}$ Herkulesa, nie pozwolę ci umrzeć, jeśli do mnie pieniądze nie wrócą, dwadzieścia min.

(33) Sed erant permulti alii ex quibus id facillime scire posset, omnes scilicet Lanuvini. /Cic. Mil. 46/

Lecz było bardzo wielu innych, od których tego z łatwością dowiedzieć się mógł, tj. wszyscy mieszkańcy Lanuwium.

W zdaniu (32) mamy do czynienia z pierwszą możliwością, tzn. viginti minae dookreśla argentum, natomiast w (33) uściślona jest treść całego wypowiedzenia: tę dużą liczbę osób, od których można było uzyskać informację stanowili wszyscy mieszkańcy miasta. Jak zauważa Spevak (2010: 113), w prozie epoki klasycznej, typ tematu określany jako tail pojawiał się jedynie w listach, mowach i dialogach, a więc w tego rodzaju tekstach, który miały oddawać odmianę mówioną języka.

Ten bardzo pobieżny przegląd wykładników struktury tematyczno-rematycznej w łacinie może jedynie dać najogólniejsze wyobrażenie o tego rodzaju środkach. Jak wspomniałam na początku artykułu, niewątpliwie najważniejszym sposród nich jest szyk. Warto zwrócić uwagę, że oprócz wielu innych zasygnalizowanych problemów, jakie wiążą się z opisem relacji między szykiem a strukturą tematyczno-rematyczną, ważną kwestię, której tu nie poruszyłam, stanowi nierzadko bardzo silne zretoryzowanie prozy łacińskiej, przejawiające się m.in. w częstym stosowaniu szyku chiastycznego, jeśli zaś chodzi o poezję, istotną rolę w uszeregowaniu składników zdania odgrywają względy metryczne. Wymienione tu inne niż szyk wykładniki tematu i rematu są stosowane w języku łacińskim w znacznie mniejszym zakresie i, jak się wydaje, służą do sygnalizowania uwypuklonej struktury tematyczno-rematycznej. 


\section{Źródła}

Caes. Gall:: C. Iulius Caesar, De bello Gallico: C. Iulii Caesaris Commentarii Rerum Gestarum, vol. 1, ed. O. Seel, Leipzig: B. G. Teubner 1961.

Cato Agr.: M. Porcius Cato, De agri cultura: M. Porci Catonis De Agri Cultura ad Fidem Florentini Codicis Deperditi, ed. A. Mazzarino, Leipzig: B. G. Teubner 1982.

Cic. Att.: M. Tullius Cicero, Epistulae ad Atticum: Cicero's Letters to Atticus, 6 vols., ed. D. R. Shackleton Bailey, Cambridge: Cambridge University Press 1965-1968.

Cic. Fin.: M. Tullius Cicero, De finibus bonorum et malorum: M. Tulli Ciceronis Scripta Quae Manserunt Omnia, fasc. 43, ed. T. Schiche, Leipzig: B. G. Teubner 1915.

Cic. Font:: M. Tullius Cicero, Pro Fonteio: M. Tulli Ciceronis Orationes, vol. 6, ed. A. C. Clark, Oxford: Oxford University Press 1911.

Cic. Mil.: M. Tullius Cicero, Pro Milone: M. Tulli Ciceronis Orationes, vol. 2, ed. A. C. Clark, Oxford: Oxford University Press 1918.

Cic. Phil.: M. Tullius Cicero, Philippicae: M. Tulli Ciceronis Orationes. vol. 2, ed. A. C. Clark, Oxford: Oxford University Press 1918.

Cic. Q. fr.: M. Tullius Cicero, Epistulae ad Quintum fratrem: Cicero, Epistulae ad Quintum Fratrem et M. Brutum, ed. D. R. Shackleton Bailey, Cambridge: Cambridge University Press 1980.

Cic. S. Rosc.: M. Tullius Cicero, Pro S. Roscio Amerino: M. Tulli Ciceronis Orationes, vol. 1, ed. A. C. Clark, Oxford: Oxford University Press 1905.

Cic. Vat.: M. Tullius Cicero, In Vatinium: M. Tulli Ciceronis Orationes, vol. 5, ed. W. Peterson, Oxford: Oxford University Press 1911.

Cic. Verr:: M. Tullius Cicero, In Verrem: M. Tulli Ciceronis Orationes, vol. 3, ed. W. Peterson, Oxford: Oxford University Press 1917.

Liv.: T. Livius, Ab Urbe condita: Titi Livi Ab Urbe Condita, vol. 1, ed. R. S. Conway, C. F. Walters, Oxford: Oxford University Press 1955; vols. 2-3, ed. C. F. Walters, R. S. Conway, Oxford: Oxford University Press 1919-1950.

Plaut. Epid:: T. Maccius Plautus, Epidicus: Plauti Comoediae, vol. 1, ed. F. Leo, Berlin: Weidmann 1895.

Plaut. Poen.: T. Maccius Plautus, Poenulus: Plauti Comoediae, vol. 2, ed. F. Leo, Berlin: Weidmann 1896.

Plaut. Pseud.: T. Maccius Plautus, Pseudolus: Plauti Comoediae, vol. 2, ed. F. Leo, Berlin: Weidmann 1896.

Quint. Inst.: M. Fabius Quintilianus, Institutio Oratoria: M. Fabi Quintiliani Institutionis Oratoriae Libri Duodecim, vol. 2, ed. M. Winterbottom, Oxford: Oxford University Press 1970. 
Sal. Cat:: C. Sallustius Crispus, Catilinae Coniuratio: C. Sallusti Crispi Catilina, Iugurtha, Fragmenta Ampliora, ed. A. Kurfess, Leipzig: B. G. Teubner 1957.

Sal. Jug.: C. Sallustius Crispus, Bellum Iugurthinum: C. Sallusti Crispi Catilina, Iugurtha, Fragmenta Ampliora, ed. A. Kurfess, Leipzig: B. G. Teubner 1957.

Varro Rust:: M. Terentius Varro, Res Rusticae: M. Terenti Varronis Rerum Rusticarum Libri Tres, ed. G. Goetz, Leipzig: B. G. Teubner 1929.

\section{Bibliografia}

Adams J. N., 1976, A typological approach to Latin word order, Indogermanische Forschungen 81, s. 70-99.

BAuer B. L. M., 1995, The Development of SVO Patterning in Latin and French. Diachronic and Psycholinguistic Perspectives. Oxford and New York: Oxford University Press.

Bauer B. L. M, 2009, Word Order, w: P. Baldi, P. Cuzzolin (red.), New Perspectives on Historical Latin Syntax. Vol. 1. Syntax of the Sentence, Berlin: Mouton de Gruyter, s. 241-316.

Bolkestein M., 1995, Functions of verb-subject order, Sprachtypologie und Universalienforschung 48, s. 32-43.

De Jong J. R., 1989, The position of the Latin subject, w: G. Calboli (red.), Subordination and Other Topics in Latin. Proceedings of the Third Colloquium on Latin Linguistics, Amsterdam: Benjamins, s. 521-540.

Devine A. M., Stephens L. D., 2006, Latin Word Order. Structured Meaning and Information, Oxford: Oxford University Press.

Dik S. C., 1978, Functional Grammar, Amsterdam: North-Holland.

Firbas J. S., 1992, Functional Sentence Perspective in Written and Spoken Communication, Cambridge: Cambridge University Press.

Greenberg J. H., 1963, Some universals of grammar with particular reference to the order of meaningful elements, w: J. H. Greenberg (red.), Universals of Language, Cambridge/MA \& London: MIT Press, s. 73-113 [wyd. II 1966].

Hofmann J. B., Szantyr A., 1965, Lateinische Grammatik, II: Lateinische Syntax und Stilistik, Munich: Beck.

Huszcza R., 1983, O pewnych uniwersaliach w tematyczno-rematycznej strukturze zdania, w: T. Dobrzyńska, E. Janus (red.), Tekst i zdanie, Wrocław: Ossolineum, s. $97-123$.

Huszcza R., 1990a, Czy istnieją zdania czysto rematyczne?, w: T. Dobrzyńska (red.), Tekst w kontekście, Wrocław: Ossolineum, s. 97-103. 
Huszcza R., 1990b, Tematyczno-rematyczna struktura zdania w językach różnych typów (Normalny podział tematyczno-rematyczny), w: T. Dobrzyńska (red.), Tekst w kontekście, Wrocław: Ossolineum, s. 55-96.

Kühner R., Stegmann C., 1962, Ausführliche Grammatik der lateinischen Sprache II. Satzlehre, Darmstadt: Wissenschaftliche Buchgesellschaft.

LöFstedt B., 1966, Die Konstruktion c'est lui qui l'a fait im Lateinischen, Indogermanische Forschungen 71, s. 253-277.

Magni E., 2009, The Evolution of Latin Word (Dis)order, w: S. Scalise, E. Magni, A. Bisetto (red.), Universals of Language Today, seria Studies in Natural Language and Linguistic Theory 76, Springer Netherlands, s. 225-251.

Marouzeau J., 1938, L'ordre des mots dans la phrase latine, vol. II. Le verbe. Paris: Les Belles Lettres.

Menge H., 2000, Lehrbuch der lateinischen Syntax und Semantik. Völlig neu bearbeitet von T. Burkard und M. Schauer, Darmstadt: Wissenschaftliche Buchgesellschaft.

Panhuis D. G. J., 1982, The communicative perspective in the sentence: a study of Latin word order, Amsterdam: John Benjamins Publishing Company.

PAnhuis D. G. J., 1984, Is Latin an SOV language? A diachronic perspective, Indogermanische Forschungen 89, s.140-159.

Pinkster H., 1990, Latin Syntax and Semantics, London: Routledge.

Pinkster H., 1991, Evidence for SVO in Latin?, w: R. Wright (red.), Latin and the Romance Languages in the Early Middle Ages, London: Routledge, s. 69-82.

Plezia M. (red.), 1998, Słownik łacińsko-polski, t. 1-5, Warszawa: Wydawnictwo Naukowe PWN.

Polo C., 2004, Word Order between Morphology and Syntax, Padova: Unipress.

Rosén H., 1998, Latin presentational sentences, w: B. García-Hernández (red.), Estudios de Lingüística Latina. Actas del IX Coloquio Internacional de Lingüística Latina, Madrid 1997, Madrid: Ediciones Clásicas, s. 723-742.

Rubio G., 2009, Semitic influence in the history of Latin syntax, w: P. Baldi, P. Cuzzolin (red.), New Perspectives on Historical Latin Syntax. Vol. 1. Syntax of the Sentence, Berlin: Mouton de Gruyter, s. 195-239.

SAfArewicz J., 1950, Gramatyka historyczna języka łacińskiego. Cz. II Składnia, Warszawa: Państwowe Zakłady Wydawnictw Szkolnych.

SAlvi G., 2004, La formazione della struttura di frase romanza. Ordine delle parole e clitici dal latino alle lingue romanze antiche, Tubingen: Niemeyer.

Somers M. H., 1994, Theme and topic. The relation between discourse and constituent fronting in Latin, w: J. Herman (red.), Linguistic Studies on Latin. Selected Papers from the 6th International Colloquium on Latin Linguistics, Amsterdam: John Benjamins Publishing Company, s. 151-163. 
Spevak O., 2010, Constituent Order in Classical Latin Prose, Amsterdam-Philadelphia: John Benjamins Publishing Company.

WeinsBerg A., 1983, Jezzykoznawstwo ogólne, Warszawa: PWN.

\section{Markers of the Thematic-Rhematic Structure in Latin}

( su m mary)

The aim of the article is to survey the markers of the thematic-rhematic structure in Latin. Since Latin is an inflected language with so called 'free' (or rather 'flexible') word order, the word order itself is the main marker of the thematic-rhematic structure. Besides word order, there are also other means serving as markers of theme or rheme in Latin. Rheme can be indicated by the cleft construction, well known in many languages. More varied markers serve to express the theme constituent. Among them there are the so-called correlative constructions quilquod... is/id, syntactically independent propositional phrases de + ablativus, the so-called nominativus pendens, and the expression quod pertinent ad... However, the means mentioned above seem to be the emphatic markers of the thematic-rhematic structure. 